Federico Rovea*

ORCID: 0000-0003-4099-8963

Padua, Italy

\title{
Education and Alteration. Notes on Personalism, Alterity and Education in Dialogue with Michel de Certeau
}

\author{
Edukacja i przemiana. \\ Uwagi o personalizmie, zmienności i edukacji \\ w dialogu z Michelem de Certeau
}

\begin{abstract}
This article tries to elaborate some insights from Michel de Certeau's works on personalism, alterity and education. The aim is to add a poorly known voice to the contemporary debate around pedagogy and personalism. De Certeau's original account of personhood, based on the movement of 'alteration' rather than on 'identity', is presented as original and useful to enrich the contemporary educational debate. The article firstly analyzes two texts where Certeau deals specifically with the role of alterity in educational contexts. The uncanny and ungraspable movement of 'alteration' will be shown as fundamental in the person's formation. Secondly, it will be argued that such account of alterity is rooted in Certeau's interpretation of the Christian tradition. Finally, it will be maintained the possibility of conceiving education itself as a process of 'alteration'.
\end{abstract}

* Federico Rovea, Department of Philosophy, Sociology, Pedagogy and Applied Psychology, University of Padua; email: federico.rovea@phd.unipd.it. 
Keywords: Michel de Certeau; alterity; personalism; educational philosophy; post-structuralism.

Abstrakt: Celem niniejszego artykułu jest rozwinięcie pewnych spostrzeżeń zaczerpniętych z prac Michela de Certeau dotyczących personalizmu, zmienności i edukacji, aby włączyć jego słabo znane stanowisko w bieżącą debatę poświęconą pedagogii i personalizmowi. Obecna w pismach de Certeau oryginalna idea osoby, opierająca się nie na „tożsamości”, a na ruchu „przemiany”, zaprezentowana jest w niniejszym artykule jako innowacyjna i ubogacająca dla bieżącej debaty o edukacji. Na początku przeanalizowane zostają dwa teksty, w których de Certeau poświęca szczególną uwagę roli zmienności w kontekście edukacyjnym. Niesamowity i niepojęty ruch „przemiany” zaprezentowany zostanie jako fundamentalny dla formowania się osoby. W drugiej kolejności wykazane zostanie, że takie podejście do zmienności zakorzenione jest $\mathrm{w}$ tym, jak de Certaeu interpretuje chrześcijańską tradycję. Jako ostatnia rozwinięta zostaje możliwość pojmowania samej edukacji jako procesu ,przemiany”.

Slowa kluczowe: Michel de Certeau; zmienność; personalizm; filozofia edukacji; poststrukturalizm.

\section{Introduction}

In recent educational research we can find many attempts at moving from a human-centered conception of education towards more inclusive approaches. Animals, natural elements, processes, objects: these are the new protagonists of some educational philosophies. These philosophies seem to put the traditional question around the nature of mankind aside, to concentrate more on other elements of reality. ${ }^{1}$ The ecological crisis and the development of digital technologies are just two of the many contemporary challenges educationalists are trying to face by elaborating new frameworks. The critique to the human-centered approach that has ruled western education until today is very popular today. The anthropocentric approach to education seems to be unable to help us thinking and dealing with these urgent issues.

${ }^{1}$ For an introduction to the main questions see Pinto Minerva \& Galelli (2004) and Snaza et al. (2014). 
Is faith in human ability to care for the world and the others to be put aside in favor of radically other forms of thinking? More specifically: should pedagogical reflection change the conception of 'person' as the fundamental addressee of educational efforts? Is it possible to conceive the challenges of today's world pedagogically, and to do so with realism but also with hope in the future generations?

In this article I would like to sketch a contribution to this ongoing discussion by engaging with some works by the French Jesuit and theorist Michel de Certeau (1925-1986). De Certeau-although he has seldom addressed pedagogical questions directly-offers some original anthropological and pedagogical suggestions rooted in the Christian tradition and attentive to contemporary social questions. De Certeau has always refused to use 'person' and 'personhood"' as valuable theoretical tools, but at the same time he can be certainly considered a humanist thinker. ${ }^{3}$ He devoted many of his works to the analysis of the procedures, 'tactics' or 'styles' where the hidden and dispersed creativity of humankind shows itself, rather than dealing with the ontological questions around personhood. ${ }^{4}$ Certeau's interest was not attracted by the definition of what human being is, but rather it was devoted to the research of those places where something 'other' - an 'excess' - to what we think a human being is, shows itself. Where and when humans can go beyond themselves? How can someone be 'altered' and become more than he/ /she is? What are the 'blind flecks' of our understanding of humanity, where something 'else' can be found? These are some of the questions posed by Certeau's works, rooted in philosophical anthropology and of great interest for educational theory.

2 This is clearly stated in the introduction of his major work The Practice of Everyday Life (de Certeau, 1988), where the author refuses to 'come back' to the person as an analytical element. Nevertheless, it is plausible that Certeau's criticism on the notion of such term refers to 'person' as a tool for social analysis and not as an ontological term. In other words, even if Certeau is clear in refusing the 'person' as the fundamental term of social analysis, it is not clear if he also intends to refuse in toto the tradition of personalism. It can also be argued that Certeau may here refer to a certain conservative and individualistic vision of personhood that is possible to renovate, as other works suggest. This latter interpretation seems to me the most plausible.

${ }^{3}$ This interpretation is inspired by Richard Terdiman (1999), who has underlined the originality of Certeau's humanism specifically in relation to his account of marginal subjectivities.

${ }^{4}$ In one of his major works, The Writing of History (de Certeau, 1992), Certeau calls 'enology' ('science of the One' or 'bringing things to One') the philosophical attitude of trying to find a unique explanation or description to a wide variety of phenomena. On the other hand, 
I will here attempt to set out the originality of Certeau's 'humanist but not personalist'-so to speak-position in relation to education. Certeau, as I will further maintain, has elaborated an original insight on the process of 'alteration' as fundamental in making experience significant: in this uncertain and uncanny ${ }^{5}$ movement (more than in the definition of what humanity is or should be) lies a possibility to rethink the process of education. I will explore Certeau's contribution beginning with his treatment of two figures: the missionary and the teacher as professionals engaged with otherness, figures that can be 'altered' by such experience (de Certeau, 2010'). These figures make clear that the quality of the relation to the other matters more than the understanding of the other. I will then describe as a third example Certeau's account of public schooling as 'marginal', as the author presents it in the text Culture in the Plural (de Certeau, 1997). In this third example the school is described as agent of 'alteration' of popular culture: instead of a place of transmission it can be described as a place where young people and culture 'alter' each other and produce new significant knowledge. I will finally try to articulate and propose the possibility of conceiving education itself as a form of 'alteration' rather than a 'formation'.

\section{The missionary and the teacher: engaging with the other}

In 1969 Certeau published a book, entitled L'Étranger ou l'Union dans la Difference [The stranger or Union in Difference], where he collected some articles previously published in different Catholic journals around questions of spirituality and Christian life. During the 1960s and 1970s Certeau was a very active member of the Jesuit's cultural projects in Paris: he published an enormous number of essays on both religious and political questions and he engaged directly in the public debates. At that time - also thanks to the radical renewal brought by the Second Vatican Council - the Society of Jesus

he calls for the human sciences in general the duty of building a 'heterology', an understanding of difference and alterity that does not erase alterity into identity.

${ }^{5}$ In this article I refer to the 'uncanny' in the meaning given by Sigmund Freud (2003).

${ }^{6}$ As an official English translation of the text L'Étranger ou l'Union dans la Difference is not yet available, every quote will be referred to the Italian version (de Certeau 2010), translated into English by the article's author. 
was on the frontline trying to build a dialogue between the Christian tradition and the secular world. ${ }^{7}$

In $L^{\prime}$ Étranger, Certeau addresses some current issues in the catholic communities: conflict and relationships, community building, the engagement of Christians in politics and education, spirituality. Such topics are nevertheless kept together by the constant reference to the experience of the other. Certeau points at the disturbing but promising experience of 'being different' as the core of Christian life in contemporary times. Like the Emmaus disciples who walk with Jesus without recognising him (Luke 24:13-35; de Certeau, 2010, pp. 15-20), Christians should acknowledge that the Lord always comes in the form of a 'stranger', someone who speaks to their hearts without being recognised:

The one who believes in Him is called to recognise Him like this: He's the one who lives far away or which is a foreigner, a difficult neighbour or a separate brother, someone met by the road, or in jail, the poor, the outcast ... God remains the unknown, the one we do not understand, even when we believe in Him: He is always a stranger for us ... (de Certeau, 2010, p. 15).

In this context, chapters three and four are particularly interesting to understand Certeau's approach to educational questions. These two sections of the book analyse the experience of two figures who are confronted with specific forms of otherness: the missionary who engages him/herself with cultural difference and the teacher who deals with the younger generation. Before further elaborating, a historical remark is necessary: during the 1960 the Catholic church and European society in general experienced some deep changes who reached a peak in the 1968 riots. The first waves of decolonisation, the establishment of consumer's society and the progressive loss of 'traditional' values are some of those major changes. ${ }^{8}$ While reading Certeau's texts it is always necessary to keep in mind the context in which those texts where written: a time of changes where some intellectuals tried to understand how traditional roles-such as the missionary and the teacher-could

${ }^{7}$ De Certeau, for instance, was one of Henri de Lubac's most promising disciples, even though their relationship grew cold because of some of de Certeau's controversial theological ideas (see Dosse, 2002b).

${ }^{8}$ Certeau himself has published a collection of articles around the events of May '68, named The Capture of Speech (de Certeau, 1997b). 
adapt to the new social situation. These two figures where still deeply related to the traditional and authoritarian values. The missionary was the symbol of cultural appropriation and of colonial mentality, and the teacher represented the power of adults over the requests of freedom and renewal from the younger generations. Certeau tried to reread the roles of the missionary and the teacher, both as 'men of the gathering' rather than 'men of transmission'. Certeau's arguments are to be understood in this historical context, so to fully understand both their historical genesis and their universal value.

Let us start with the figure of the missionary. The task of the missionary is generally considered evangelisation: travelling around the world to bring the Gospel and the Church's teaching to those who do not know them yet. ${ }^{10}$ He knows something and tries his best to bring his knowledge to the others. In Certeau's words his

preoccupation to elaborate apostolical techniques designed on his listeners will make him/her use the knowledge he has about them. Working on them rather than with them, he will be interested in their language as an instrument to use. This is not yet an encounter (de Certeau, 2010, p. 71).

The missionary, in other words, usually considers those he meets as mere objects: he tries to understand them to transmit them his message more effectively. ${ }^{11}$ The missionary studies and tries to comprehend the other's culture only in an instrumental way, as something useful for his personal purpose. This conceived, the relation between the missionary and the people is merely instrumental, it is not a real encounter, but it more closely resembles a conquest of the other. In other words, between the missionary and the other there

9 Certeau introduces the expression 'men of the gathering' to describe the missionary and the teacher as those whose mission is to build significant relationships with others rather than transmitting some knowledge.

${ }^{10}$ It is not without significance the fact that Certeau, a Jesuit, was interested in the mission. Actually, as reported by François Dosse (2002a; 2002b) Certeau's decision to join the Company of Jesus was determined by the fascination for the missionary tradition (especially in the figure of Matteo Ricci) and Certeau himself was determined to become a missionary in China. Although this desire was never met by the Jesuit superiors, Certeau's sensibility for cultural otherness is clearly visible in his writings and his life experiences.

11 This description echoes in what Paulo Freire has famously described in the same period as 'banking education' (2005): the critique to traditional ways of teaching was evidently an urgent issue at the time. 
is no real encounter, because the other is considered as an object and not as another subject. ${ }^{12}$

Furthermore, the missionary risks also to annihilate, so to say, the otherness by reducing the other to his own personal history. In the missionary's eyes, the others are the passive receiver of his message, they do not have a voice or something valuable to say. They are just projections of the missionary's own vision:

By reducing the others to objects of his/her certainties, he/she [the missionary] incorporates them into his personal history, without leaving them the freedom to invent a story of their own; and as he does not recognises them their right to be themselves, he/she forbids him/herself the possibility to meet them (de Certeau, 2010, p. 81) $)^{13}$.

After having outlined this situation, Certeau proposes to overturn this vision of the mission, by describing the missionary as the one who 'does not have, essentially, the purpose of "conquering", but rather of recognizing God where He has never been recognised before' (de Certeau, 2010, p. 17).

According to Certeau, the missionary's duty is exactly the opposite of what is commonly thought: instead of having to bring some knowledge to the other, he has to recognise God in the other, he has to let God speak to him in foreign languages. Thus considered, the mission is no longer a conquest, but it becomes more like a research. Certeau is here affirming that the knowledge of the other is always limited and limiting, it always risks of being a form of self-defense from the other's uncanny presence. The quest for the unexpected other is certainly more demanding but is also the only way to a real encounter. Letting the other be himself-letting him speak in his own voice-is according to Certeau the only way to authentically meet him and, consequently, to recognise the divine in him.

This change of perspective is not simple neither automatic. Accepting the other is destabilising, is a threat to one's own identity. Certeau relates the

12 A very similar account of the relation to the other can be found in Martin Buber's famous distinction between the I-it and the I-Thou relationship. Only the latter should be considered as a real form of encounter (Buber, 2008; Milan, 2000).

${ }^{13}$ Certeau is here addressing a common vision of the mission, he is not directly criticizing the work of missionaries. 'The missionary' should be here considered as a reference to such idea of 'the mission' in general. 
experience of otherness to Abraham's voyage through the desert, when he 'leaves without knowing his destination, willing to listen to God's word in a foreign land' (de Certeau, 2010, p. 17). The experience of the encounter with the other, following with the biblical reference, is a contemporary form of the experience of the 'desert'. The desert is the place where one's own identity is proven and one's faith can be renewed: so is the experience of an authentic encounter with otherness.

The destabilising nature of the encounter with the other is also at the center of Certeau's account of the figure of the teacher. In this second case the author does not move from a critical remark-as it was the case for the missionary-but he starts with the description of a common experience:

Anna is starting to talk. She is just sixteen months old, but she already moves towards you and tries to talk to you. Is it a question, an expression of love or the narration of a success? It is impossible to know ... Your word comes back to you from the place it has awakened, and you already do not recognise it in this hidden meaning poem: born from a love, now it reveals to you the existence of your child (de Certeau, 2010, p. 45).

Anna is the name of an infant who is starting to talk. She cannot pronounce complete words or sentences yet, so she makes noises and sounds to express herself. Certeau reads in this event not only the baby's first step towards the mastery of a language, but rather something more fundamental. Anna is not just trying to repeat what her educator taught her: she is, in a sense, inventing her own words, trying to say with those senseless sounds 'I exist'. ${ }^{14}$ The educator, who is trying to teach her the language and so expects her to repeat his words, is displaced: his words are 'stolen' by the baby, who is symbolically affirming her existence as someone different from her educator. In a sense, 'the emergence of the child coincides with that of a new world' (de Certeau, 2010 , p. 45): along with the baby's sounds there is a new world announcing itself, a world that already escapes the educator's control.

Metaphorically, this situation can be extended to educators (and to pedagogy) in general. Every educator, Certeau claims, at one given moment

14 This description echoes in a more mature text exploring the phenomena of glossolalia, seen as an event that 'permits saying to take place' (de Certeau, 1996, p. 38). De Certeau points at glossolalia and at the baby's sounds as foundational events, in the sense that both are pre-linguistic expressions that open the possibility for a language to exist - they 'begin' a language without really being part of it. 
experiences a 'dispossession' of his/her own words in front of the younger generation. She/he can feel that 'he is no more giving the speech to others: they are taking it' (de Certeau, 2010, p. 46). The 'dispossession' of the educator's speech also coincides with the end of what Freire has called 'banking education': the educator cannot anymore consider himself as the only voice to speak in the classroom or as the unique holder of knowledge. The young are taking the educator's words and making something different with them, this way approaching the world in a unique and original way. The 'dispossession' of the speech-Certeau seems to suggest-is a fundamental part of the educational process: just like the missionary feels lost when he is confronted with cultural difference, the teacher feels speechless in front of a younger generation that wants to speak in its own voice. When the other is left free to express-these examples suggest-some instability is produced in the identity of those who meet, and such instability holds the promise of something new to happen.

To sum up these first two examples: the figures of the missionary and of the teacher show that according to Certeau the knowledge of the other is not useful but, exactly at the opposite, it closes the possibility to authentically meet the other. Knowing or pretending to know who the other is-an attitude typical in personalist approaches-arrests the possibility for an 'alteration' to happen: the pupil that 'dispossesses' the teacher of her/his knowledge is producing new knowledge and relationships, while when he is treated as a passive receiver of contents nothing new can be produced. Similarly, the missionary who tries to know more about the others to teach them more effectively his own message, is actually making an authentic encounter impossible. In other texts the author (de Certeau, 2005; 2006a) describes the attitude to the annihilation of difference as 'scriptural tension' of 'scriptural economy': typical of western European culture, the 'scriptural tension' represents the habit of comprehending different elements into one singular framework that explains them. Just as when one is writing, one puts different elements or different stories into one singular narration that comprehends and explains them, the 'scriptural' functioning affects also pedagogy and education, in the form of the need to explain the other's behaviour or identity. The writing is the visual representation of the attitude that fears difference, that feels safe only when a general explanation is at disposal.

For this reason, Certeau was so interested in the uncanny and fearful character of the meeting with the other: those characteristics guarantee that the experience of gathering is authentic, that we are confronting something 
at the same time ungraspable and promising. ${ }^{15}$ In other words, if we put our attention on the process of 'alteration'-rather than on the 'definition' of what is and what should be-we leave space for something unexpected to happen ${ }^{16}$ and we try to overcome the 'scriptural' tension that has ruled western culture.

To sum up, the example of Anna's educator maintains that education-from its very beginning-is an uncanny process of relationship to another. The otherness of the baby cannot be 'domesticated' without undermining the quality of the relationship itself. Therefore, education involves a relationship with another person who presents him/herself to the educator as unrecognisable, ungraspable, but also with the promise of enriching alterity.

\section{Schooling as a 'marginal' activity}

Another significant example of Certeau's interest in the movement of 'alteration' in relation to education can be found in a more recent text named Culture in the Plural (de Certeau, 1997a). This collection of essays was firstly published in 1974 and deals mostly with questions of 'popular culture'. Anticipating the evolution of the field of Cultural Studies ${ }^{17}$-that actually was greatly inspired by some of Certeau's works-the author proposes a critique of some aspects of common culture such as advertising, the institution's authority, the treatment of minorities in society, mass communication and many others. Once again, the element that keeps together a book with such different topics, is the willingness to show how alterity works in the context of popular culture and produces meanings. Popular culture-the book's title itself suggests it-is in itself plural and such plurality should be studied as it is, not reduced to a singular and unifying interpretation. Certeau here uses

15 The account of the uncanniness of the experience of otherness was inspired by the long attendance to the psychoanalytical seminars hold in Paris by Jacques Lacan. Indeed, Certeau was an active member of the École Freudienne de Psychanalyse and a passionate psychoanalysis reader. Although he has never considered himself an analyst, Certeau has originally used psychoanalysis as an analytical framework in most of his works. See for instance de Certeau (2006b).

${ }^{16}$ This concept has been framed in a very effective way recently by the philosopher of education Claudia Ruitenberg. Inspired by Jacques Derrida's philosophy-which shares many different elements with Certeau's-she has described the necessity for educators to always 'leave an empty chair' (Ruitenberg, 2011), it is to say that every educational activity should be attentive to what or who can show up unexpected.

17 See for instance Buchanan (2000). 
the instruments of semiotics, of anthropology and of social philosophy ${ }^{18}$ to analyse 'popular culture' and to show the richness and the problematic nature of what was at the time still considered just a deteriorated form of 'high' culture.

In this context he introduces the concept of 'marginalisation' (de Certeau, 1997a, pp. 37-69; Terdiman, 1999) as useful to understand contemporary society. The term 'marginalism' according to Certeau does not point at groups or individuals that cannot fully participate in society's life. The term rather describes the situation of the majority of the population: facing the fast growth of mass communication and of giant cultural industries, the population as a whole is 'marginalised', in the sense that it is excluded from the production of culture. The more the cultural production gets concentrated in the hands of a small group of entrepreneurs and professionals, the more most of the population is reduced to a mere spectator or receiver. ${ }^{19}$ Even if according to Certeau it is not possible to reduce the human subject to a mere passive receiver of content, ${ }^{20}$ the general cultural discourse of his times tries to promote this kind of message.

${ }_{18}$ Culture in the plural can be read in parallel with another foundational text of cultural critique: Mythologies by Roland Barthes (2016). Indeed, Certeau was a reader and estimator of Barthes' works (see also Barthes, 1977), so the influence of Mythologies is probably present in Culture in the plural, although not explicitly. In both texts the instruments of semiotics are used to interpret elements of popular culture, with an obvious difference: in Barthes' case the object of critique is the dawn of consumer's society (the first forms of mass communication, advertising etc.) while de Certeau faced a more mature phase of European capitalist society, so he dealt with different issues (authority, advanced consumerism, migration and minorities etc.) (see Facioni, 2019).

19 Among the many different examples of scholars that have pointed out the same situation during the 1970s we can remember two authors that have tried to propose some pedagogical responses: on one hand Ivan Illich (2009; 2013; Hartch, 2015) is certainly among the first to have reclaimed for the people the need to be protagonists of the cultural production, on the other hand the Italian writer and film director Pier Paolo Pasolini (1975) have extensively criticised the use of television as a form of education and have stimulated alternative solutions. These claims seem to be outdated, given the change brought by the spread of digital technologies. Everyone-owning a smartphone-seems today able to produce some form of cultural content. On the other hand, nevertheless, the decision over the functioning of the algorithms that govern the internet platforms seems to reproduce and to radicalise the concentration of cultural power into a small group of people (see for instance Bucher, 2018).

20 This position is already outlined in Culture in the plural but is fully developed in his work The practice of everyday life (de Certeau, 1988), which is completely devoted to the description of the 'tactics' employed by the average human being to escape the constraints of consumer society. 
Schools and universities are not excluded from this cultural situation. Scholarly knowledge is discredited in front of more effective and fast ways of spreading information and contents (via the mass media), and the purpose of schooling itself seems to be in danger. If television and papers-but this seems even more urgent today considering the spread of social media-can communicate and create knowledge in a fast and effective way, what is left for the school? Indeed, Certeau claims that

To the very extent that scholarly knowledge is discredited when it is replaced by more profitable types of knowledge acquired elsewhere, when it is no longer so closely linked to the law of a society, it is perceived more as the artifice that conceals the more 'real' conflicts of communication ... The more knowledge is marginalised, the more relational problems invade the areas it had inhabited. ... Schools could be one of the places where it is possible to relearn the connection by way of a particular practice. Already, in a fashion that has become minor, they permit experimentation with this: they constitute a laboratory in which this social problem is somehow miniaturised, but remains visible and can be addressed (which does not mean that it can be resolved), as long as the terms are made explicit (de Certeau, 1997a, p. 57).

Certeau is here maintaining that the role of schooling is in crisis because given the present situation-where the role of transmitting cultural contents is completely absorbed by mass media-schools have lost their traditional role of transmitting the society's cultural heritage. 'Schools are no longer the warehouse that distributes orthodoxy in the form of social practice' (de Certeau, 1997a, p. 58), the author further maintains. Schools are 'marginalised' because the center of cultural production and transmission now lies in the communication industry and the traditional role of transmission of content is taken away from schools. In this claim we can certainly recognise the influence of the May ' 68 revindication of a non-authoritarian way of educating the young, ${ }^{21}$ but far from being just a reflex of that time, Certeau's reflection

${ }^{21}$ Certeau, already as a university lecturer, supported the '68 protests and he was an original and attentive observer of the radical transformation that the event of ' 68 brought into French society (see de Certeau, 2007). Nevertheless, he was also very critical regarding some of the cultural outcomes of the period: for instance, he openly criticised Bourdieu and Passeron's La Reproduction because of their insistence on the impossibility for schooling to foster societal critique. Even if he shared the social critique on the institution of the school, Certeau has always been trustful in the possibilities of changing society through education (de Certeau, 1979; 1988). 
poses some fundamental questions about school's role in mass communication societies. Certeau tried to describe a new social situation without giving immediately a moral evaluation but trying to understand the implications and the possible developments. The question-still urgent today-is: what is today the social role of schooling, given the fast-growing power of mass communication that seem to make schooling obsolete?

The situation of 'marginalisation' of schools can be turned into a resource, Certeau suggests. The author indeed points at 'marginalisation' as the possibility to rediscover the role of schools not as places of transmission but as places of 'practice' of culture. The contents of knowledge (the simple information), as already maintained, can be found more rapidly elsewhere, but in the school can be done something different and more fundamental than just accessing information. The school is the place where information is practiced, is discussed, and is given sense to, where 'information is made into an element of formation' (de Certeau, 2010, p. 53). In the school information is socialised, criticised, and becomes part of a collective experience: information becomes formation as long as it is made part of a living experience of relation to the other.

Following on the same argument, Certeau also maintains that schools now must take up a more critical role in relation to popular culture. Indeed, in the modern era schools have almost always been looked at by governors as a useful instrument of ideological transmission and 'informal' educational places were the places where critique was practised (let us think of the central role of cafés during the French Revolution). The late modern social situation is almost the opposite, as

cultural power is no longer localised in a school but is diffused into every farmhouse and every room with television screens. It is 'personalized'. ... That changes the position of the school. Formerly, as a representative of the pedagogical state, the school had as an adversary the family that played a controlling role. ... Today, the school is in an almost opposite situation: with regard to the family invaded by the televised image, it can become the site of control where are learned the uses of an information that is henceforth given outside of the school (de Certeau, 1997a, p. 64).

If power is held via mass communication, then the school must become the place where such power is challenged and criticised. In the school all the information and the solicitations gathered by students can be looked at 
with critical distance, allowing them to decide freely what to do with them. ${ }^{22}$ In other words, the critical role of schooling is today way more linked to the quality of the relation to information, rather than to the quality of the information itself. This is not to say that the quality of the information given at school is not of pedagogical importance, but rather that if we look at schooling in the context of contemporary popular culture caring about the process of a good relation to the content is more urgent. The information in school can be 'altered' by the 'practice': every aspect of popular culture can be turned into something valuable, different and renewed.

We can see again in this account of schooling the focus by Certeau on the process of 'alteration'. Schooling is not described as process of formation in a teleological sense: Certeau has never tried to elaborate an account of what are the aims of education, or how a 'well educated' man or woman should look like. This attitude was beyond his interests. Schooling was instead described as a process-or a 'practice" ${ }^{23}$-of production of difference rather than the pursuing of a specific goal. The cultural elements gathered by the young in their everyday life should be re-written, re-signified and re-interpreted at school. The young can make something different with culture, can be authentically questioned and can authentically renovate his own culture. This can be seen, again, as a process of mutual 'alteration' between the student and culture (but also between the student and the teacher) which does not produce measurable and specific outcomes, but leaves the space open for the unexpected and the new to happen.

\section{Christianity, or 'the religion of the Other'}

Until this point I have tried to show-via the examples of the missionary, the teacher and the schools-that Certeau's account of educational processes is focused on movements of 'alteration' rather than on 'persons' and their

${ }^{22}$ This idea was recently developed-although building on sources other than Certeau's works-by Jan Masschelein and Maarten Simons (2013). They claim for the school the role of 'profanation', meaning that the school must allow the young to take culture and re-invent it, criticise it, and use it differently. In school cultural products must be 'put on the table' and looked at together, demystified and, so to say, re-framed.

${ }^{23}$ The term 'practice' is used by Certeau in a very specific sense we unfortunately cannot explore in the space of this article. Let us, with an oversimplification, consider it as the specular other of codified actions, all those acts that are not sustained by a theoretical discourse (see de Certeau, 2006a, pp. 153-215; 1988, pp. 43-91; Brammer, 1992; Giles, 2014). 
formation, and that this position can be seen as humanist although non personalist. Because of this original position, I propose that Certeau should be considered a useful contributor to the philosophy of education discussion. In this section I would like to give some insights on the origin of Certeau's account of 'alteration', which is inspired by the author's account of Christianism as the 'religion of the Other' (de Certeau, 2010). Indeed, as Giuseppe Riggio maintains

Certeau does not hide the influence that Christianity had on the Western's view of alterity. In a certain sense, alterity is inscribed in Christianism's genetic code. Christianism did not rise a new and autonomous religion, but it rather is a form of hermeneutics of the other, where the other is in the first place Judaism (Riggio, 2016, p. 125). ${ }^{24}$

Certeau considered the origins of Christianity as one of the foundational moments of Western Culture. Indeed, Christianity instead of being born as an autonomous religious movement initially acted as a form of renovation of Judaism..$^{25}$ Christianity, in other words, was originally an 'alteration' of Judaism, something new and unexpected that grew within someone else's space. Christianism inaugurates a particular cultural and religious gesture that deeply characterises western culture: the rise of something new as an 'alteration' of an existent culture, religion, or knowledge. Christ Himself acted as the unexpected other inside the Hebrew community and from this encounter something radically new has risen:

Globally, this neo-testamentary writing did not mean to be the truth instead of the previous one, or to substitute one religion with another one, but aimed at connoting a kind of conversion opened by Jesus, and which will indefinitely be ahead, to be done (de Certeau, 1987, p. 223). ${ }^{26}$

24 'Certeau non tace l'influenza che il cristianesimo ha potuto esercitare nel tempo sullo sguardo dell'Occidente a proposito dell'alterità. In un certo senso, l'alterità è iscritta nel codice genetico del cristianesimo, che non è sorto come una religione nuova e autonoma, ma è piuttosto un'ermeneutica dell'altro, dove l'altro è stato innanzitutto l'ebraismo'. Translation by the article's author.

${ }^{25}$ For a precise account of Certeau's interpretation of the Christian origins see Quirico (2005).

26 'Globalement, cette écriture néo-testamentaire n'avait pas pour signification d'être la vérité à la place de la précédente, ou de remplacer une religion par une autre, mais de conno- 
This original movement of Christianism as 'alteration', furthermore, is not exclusively a feature of the origins, but it runs all along Christian history. The relation between the New and the Old Testament testifies the same dynamic: the Gospel is not given to mankind 'to abolish the Law or the Prophets ... but to fulfill them' (Mt 5:17). It is again a form of 'alteration' that characterises the relationship between the sacred texts, the one cannot go without the other but at the same time the one affects and changes the reading of the other.

In addition, we can see the same dynamic at work in other examples: the existence of the four Gospels-the same story of salvation told in four different manners, all the four sacred in the same way but each one affecting the others; the existence of different Christian Churches-different interpretations of the same foundational event; and finally, on a more personal level, the existence of different sensibilities and different personal stories inside the Christian community: 'Nobody is Christian without the others, and a community cannot call itself Christian if not authorised by a necessary relation to others' (de Certeau, 1987, p. 214) $)^{27}$.

The truth of Christianism, states Certeau, is that "the most "essential" is what escapes the most' (de Certeau, 1987, p. 112) ) $^{28}$ t the truth lies 'in between'-between different texts, communities and people-and is not fixable in a single text or in a single interpretation. Christ's message is primarily not a doctrine that states some truth, but is a call to a conversion or, to take up once again Certeau's vocabulary, to an 'alteration' of one's own life. Certeau

ter un type de conversion désormais inauguré per Jésus, et qui serait indéfiniment à «faire»'. Translation by the article's author.

27 'Nul n'est chrétien sans es autres, et aucune communauté ne saurait se pretendre chrétienne sans y être autorisée per un rapport nécessaire à d'autres' (Translation by the article's author). Certainly, this consideration of the relationship among different as the core of Christian faith is rooted in the Trinitarian dogma. Certeau seldom refers directly to Trinitarian relations (one example can be found in de Certeau [1987, pp. 212-215], where he addresses the relation of reciprocal otherness and unity between the Father and the Son) but his descriptions of 'alteration' movements terminologically recall the dynamics of kenosis and perichoresis. We could interpret this sort of 'hidden reference' to Trinity in the light of Certeau's more general attitude facing the relation between Christianism and the secular world: Trinity acts at a backdrop, something that structures thoughts without being directly addressed. Trinity, we could add, works as the hidden origin of Certeau's reflections that remains in the dark in order to make the reasoning 'work'.

28 'Le plus "essentiel” est ce qui échappe le plus'. Translation by the article's author. 
sees the most fundamental truth of the Christian message in a movement of 'alteration' started by Christ himself, which can never be fully accomplished. Such message call for a continuous and destabilising encounter with otherness. The theologian Stella Morra describes this interpretation as follows:

The errance and the travels that makes Certeau a seeker of thresholds and places of transit are always travels towards God ... It is believer's quest, restless, in which the soul does not interfere with intellectual rigor and honesty, and in which science is not a pretext (of better a pre-text, condition a priori) to distrust faith; the two approaches nourish one another and, as it is right to be, science constitutes a body, a visibility, a readability, a possibility of language to the silent wanderer the believer is (Morra, 2004, p. 38). ${ }^{29}$

There is an expression, very often used by Certeau, that helps further understand his account of the role of alterity in Christianism: the other is 'necessary and absent'. The other-be it in the form of the other person, the other community or Christ Himself-who produces an 'alteration' of identity is at the same time necessary and never fully accessible. The experience of otherness-Certeau is very clear on this point-is not understandable, is uncanny and fearful: you can never know what to expect from the other. The existence of otherness-described in psychoanalytic terms-is a deadly threat to identity because it affirms that my existence is limited and, ultimately, it recalls my death. The experience of otherness is so nothing peaceful, but-just as the Crucifixion lead to Resurrection-the dreadful experience of alteration is the only way to significance: "Making room for the other also means receiving the grace of participating to a life that exceeds us and goes further than us' (de Certeau \& Domenach, 2010, p. 50) ${ }^{30}$.

29 'Le erranze e il viaggio che fanno di de Certeau un cercatore di confini e di luoghi di transito, sono sempre un viaggio verso Dio ... È una domanda credente, inquieta, in cui l'anima non deruba l'onestà intellettuale e il rigore, e in cui contemporaneamente la scientificità non diventa pretesto (o meglio pre-testo, condizione a priori) per diffidare della fede; anzi, i due approcci si nutrono a vicenda e, come è giusto che sia, la scientificità costituisce un corpo, una visibilità, una leggibilità, una possibilità di lingua circolante, al silenzioso viandante interiore che è il credente'. Translation by the article's author.

30 'Far posto all'altro significa anche riceverne la grazia di partecipare a una vita che ci supera e va più lontano di noi'. Translation by the article's author. 


\section{Conclusion: alteration as education, education as alteration}

I have underlined as an introduction the necessity of finding new anthropological and pedagogical frameworks expressed in recent pedagogical research. Then, I have presented some examples of de Certeau's account of 'alteration' as the fundamental movement of education. The examples of the missionary and the teacher have illustrated the movement of 'alteration' at work in particular contexts. 'Alteration' has emerged as the promising process of reciprocal influence; it describes a form of openness to the other at the same time fearful and hopeful. The example of schools as 'marginal' subjects has, instead, explored the process of 'alteration' on a more institutional level. Schools have been described as the places where information and knowledge are not simply transmitted, but is discussed, socialised, renovated and in so doing, made significant. Schools have so been described as agents of 'alteration' of popular culture. Finally, I have briefly explored the roots of Certeau' idea of 'alteration' in his Christian faith. Christianism, described by Certeau as 'the religion of the Other', is the primary source and the inspiration for the author's quest for otherness in every aspect of the social and cultural life.

As already stated, Certeau never intended to give a systematic account of the educational process. ${ }^{31}$ Nevertheless, moving from the examples explored we can try to sketch some features of a possible account of education as 'alteration'. Such account will be characterised by the faith in the unexhausted possibilities of human creativity and by the refuse of a philosophy of education that pretends to state once for all how a well-educated man or woman should look like.

First, Certeau shows that criticising the human-centered paradigm in anthropology and education does not lead to a loss of faith in humanity. Quite the opposite: focusing on the process of 'alteration' rather than on 'persons' leaves space for the unexpected and unknown to show. ${ }^{32}$ A different form of

${ }^{31}$ Some scholars have tried to elaborate Certeau's pedagogical insights, especially referring to his later works. See for instance Jacomino (2016), Séradin (2016), Zoletto (2012).

${ }^{32}$ I do not intend here to criticise or neglect the Christian personalist tradition per se. Authors like Maritain (1938) and Ricoeur (2005) have underlined the central role of alterity in the person's identity sharing with Certeau's thought more than a similarity. Certeau's account of 'alteration', nevertheless, is useful to radicalise the openness of the person's identity and to think of more hospitable forms of identification. It is possible to see Certeau's criticism of 
faith in the human possibilities is consequently present, a faith in the destabilising encounter with the other, in the deeply incomprehensible but promising experience of being changed by the contact with someone (or something) different. The value of this remark is both theoretical and practical: theoretically it encourages the researcher to engage with process and with the 'blind flecks' of theory, where the novelty hides; practically it pushes the educator to be a courageous listener of the other's voices and to cultivate the faith in the creative possibility of an authentic encounter.

Secondly, we can find in Certeau's texts a useful framework to tackle some of the contemporary problems of educational theory and practice. For instance, the French theorist Michel Serres recently wrote about the role of schooling:

What to transmit? Knowledge? It is already available and objectified on the web. Transmit it to everyone? Knowledge is already accessible to everyone. How to transmit it? Done! With access to people through cell phones, and access to places through GPS, access to knowledge is now open. In a certain manner, it has already been transmitted, always and everywhere (Serres, 2015, p. 11).

This passage shares with Certeau's account of schooling more than a similarity. Serres testifies that the crisis of education Certeau referred to is still present and, in a certain sense, is today even more radicalised by the rapid diffusion of digital technologies. The question of the sense of schooling in contemporary society seems to be still open. Considering-following Certeauthe role of schools as 'marginal' places, where is done a work of 're-writing' of culture seems to be a good path to find again the sense to one of the central societal institutions. Once again, 'alteration' as the horizon of educational practices-authentically engaged with otherness-seems to be a useful contribution to the necessary renovation of education.

\section{References}

Barthes, R. (1977). Sade, Fourier, Loyola. La scrittura come eccesso. Torino: Einaudi.

personalism as the desire to extend the notion of person considering the challenges of contemporary society. 
Barthes, R. (2016). Miti d'oggi. Torino: Einaudi.

Brammer, M. (1992). Thinking practice: Michel de Certeau and the theorization of mysticism. Diacritics, 22(2), 26-37.

Buber, M. (2008). I and Thou. Edinburgh: T. \& T. Clark.

Buchanan, I. (2000). Michel de Certeau. Cultural Theorist. London: SAGE Publications.

Bucher, T. (2018). If...then. Algorithmic power and politics. Oxford: Oxford University Press.

De Certeau, M. (1979). Ecole et cultures: Deplacer les questions. Université de Genève.

De Certeau, M. (1987). La faiblesse de Croire. Paris: Seuil.

De Certeau, M. (1988). The Practice of Everyday Life. Berkeley: University of California Press.

De Certeau, M. (1992). The Writing of History. New York: Columbia University Press.

De Certeau, M. (1996). Vocal Utopias: Glossolalias. Representations, 56, 29-47.

De Certeau, M. (1997a). Culture in the Plural. Minneapolis: Minnesota University Press.

De Certeau, M. (1997b). The Capture of Speech and Other Political Writings. Minneapolis: Minnesota University Press.

De Certeau, M. (2005). La scrittura dell'altro. Milano: Raffaello Cortina.

De Certeau, M. (2006a). La scrittura della storia. Milano: Jaca Book.

De Certeau, M. (2006b). Storia e Psicoanalisi. Tra scienza e finzione. Torino: Bollati Boringhieri.

De Certeau, M. (2010). Lo straniero o l'unione nella differenza. Milano: Vita e Pensiero.

De Certeau, M. \& Domenach, J.-M. (2010). Il cristianesimo in frantumi. Cantalupa: Effatà.

Dosse, F. (2002a). Michel de Certeau: Jalons d'un itinéraire. Espaces Temps, 80, 5-6.

Dosse, F. (2002b). Michel de Certeau. Le marcheur blessé. Paris: La Découverte.

Facioni, S. (2019). La parola scissa. Certeau e Barthes interpreti di Ignazio di Loyola. Bollettino Filosofico, 34, 170-178.

Freire, P. (2005). Pedagogy of the oppressed. Transl. M. Bergman Ramos. New York-London: Continuum.

Freud, S. (2003). The uncanny. London: Penguin.

Giles, G. (2014). The Concept of Practice, Enlightenment Rationality and Education: A speculative reading of Michel de Certeau's TheWriting of History. Educational Philosophy and Theory, 46(3), 255-268.

Hartch, T. (2015). The prophet of Cuernavaca. Ivan illich and the crisis of the West. New York: Oxford University Press. 
Illich, I. (2009). Descolarizzare la società. Una società senza scuola è possibile? Milano: Mimesis.

Illich, I. (2013). La convivialità. Milano: Red Edizioni.

Jacomino, B. (2016). Le pédagogue et la mort: Penser l'éducation avec Michel de Certeau. Le Philosophoire, 45(1), 105-119.

Maritain, J. (1938). True humanism. New York: Scribner.

Masschelein, J. \& Simons, M. (2013). In defense of the school: A public issue. Leuven: E-ducation, Culture \& Society Publishers.

Milan, G. (2000). Educare all'incontro: La pedagogia di Martin Buber. Roma: Città Nuova.

Morra, S. (2004). «Pas sans toi». Testo parola e memoria verso una dinamica ecclesiale negli scritti di Michel de Certeau. Roma: Editrice Pontificia Università Gregoriana.

Pasolini, P. P. (1975). Scritti Corsari. Clea: Mondadori.

Pinto Minerva, F. \& Galelli, R. (2004). Pedagogia e postumano: Ibridazioni identitarie e frontiere del possibile. Roma: Carocci.

Quirico, M. (2005). La differenza della fede. Singolarità e storicità della forma cristiana nella ricerca di Michel de Certeau. Cantalupa: Effatà.

Ricoeur, P. (2005). Sé come un altro. Milano: Jaka Book.

Riggio, G. (2016). Michel De Certeau. Brescia: Morcelliana.

Ruitenberg, C. W. (2011). The Empty Chair: Education in an Ethic of Hospitality. In R. Kuzman (ed.), Philosophy of Education (pp. 28-36). Urbana: Philosophy of Education Society.

Séradin, J.-Y. (2016). Penser Avec Michel De Certeau. Une Pédagogie Du Quotidien. Lyon: Chronique Sociale.

Serres, M. (2015). Thumbelina. The Culture and Technology of Millennials. London-New York: Rowman \& Littlefield.

Snaza, N. et al. (2014). Toward a Posthuman Education. Journal of Curriculum Theorizing, 30(2), 39-55.

Terdiman, R. (1999). La marginalité de Michel de Certeau. Rue Descartes, 25, 141-158 .

Zoletto, D. (2012). Lo spazio di intervento pedagogico di Michel de Certeau. Paideutika, VII(15), 59-74. 
